\title{
On Leadership Education of University Students: A Case Study
}

\author{
Jia-Jie WANG \\ Secretary of Youth League Committee \\ Shanghai University of Engineering Science, SUES \\ Shanghai, China \\ E-mail: ep28@163.com
}

\begin{abstract}
This article focuses on the five salient problems faced by university leadership education. Taking Shanghai University of Engineering Science as an example, this study (1) designs creative plans for leadership education of university students with the characteristics of integration of resources, advocate of teamwork, set-up of leadership courses; (2) illustrates new ideas and strategies of improving leadership education.
\end{abstract}

Keywords-integration of resources; teamwork; leadership courses; leadership education

\section{INTRODUCTION}

As an important part of cultivating talents in the new era, leadership education in China has been booming. An increasing number of colleges and universities have set up various programs of leadership training. They achieved success to some extent, yet it is still necessary and moreover pressing to find out how to further improve leadership education for students at tertiary level.

\section{FIVE MAJOR PROBLEMS IN LEADERSHIP EDUCATION OF UNIVERSITY STUDENTS}

\section{A. Focus on Elite Students, Neglect Common Students}

Some leadership education programs are only aimed at a minority of elite students from selection to cultivation at the neglect of a majority of common students who also entertain the hope of learning to improve their leadership skills. Of course, limited educational resources including teaching staff partly contribute to the situation that a broader student group is not included in the programs.

\section{B. Focus on Uniformity, Neglect Special Needs}

Some leadership education programs pay too much attention to uniformity of teaching contents. Although the unified teaching pattern is convenient for extensive instruction, it disregards a wide variety of students' needs, lacking education targets based on types of industry and social status. Students who are going to enter into various working fields not only need to have a good command of common knowledge of leadership but also master specific leadership skills with regard to the particular industry or type of work.

\section{Focus on Skills Instruction, Neglect Moral Education}

Some leadership education programs attach too much importance to skills, even schemes, in order to realize personal values quickly. Under this circumstance, leadership education is somehow connected with vulgar definitions of success. The essence of leadership education of university students is to cultivate students who would fulfill core values of socialism. Therefore, both positive skills instruction and moral education are necessary to help students establish healthy life values.

D. Focus on Forms of Activities, Neglect Systematic Frame

Some leadership education programs focus on carrying out various activities at the neglect of the top-level design of systematic education. Some activities are only aimed for finishing tasks or for particular occasions without educational function or lack of connectivity which result in insufficient understanding of leadership knowledge and low study efficiency despite participating in many activities.

\section{E. Focus on Internal Training, Neglect external Information}

Some leadership education programs only make use of internal resources for training at the neglect of information outside universities. Students will enter into broader society, so lack of education based on social resources would affect the overall quality of leadership education adversely. Meanwhile, due to the limited experiences and scope of knowledge of university teachers, it is difficult to launch leadership education programs on full scale with the sole support of teaching staff.

In the long term, the five questions mentioned above would make leadership education for students at tertiary level stagger and restrict more students from better leadership training. 


\section{A CASE STUDY: LEADERSHIP EDUCATION FOR STUDENTS OF SHANGHAI UNIVERSITY OF ENGINEERING SCIENCE}

Since 2014, Shanghai University of Engineering Science first studies comparatively the characteristics of talents training and leadership education programs of both domestic and foreign universities, then takes into consideration school's education orientation, characteristics and goals, and finally designs the specific leadership training plans for students.

\section{A. Integration of Resources}

\section{1) Make Use of Social Resources}

Broaden horizons by hosting lectures delivered by famous experts and inviting educationalists, successful businessmen and other celebrated people to give lessons.

Make teaching plans clear with the help of experts. With social resources involved, theoretical research of leadership and education plans can be improved.

2) Make Use of High-End Resources

Probe into broad society. Organize students to visit government sectors, corporations and public institutions and talk with many companies on joint programs of talents training with the eye to cultivating future administrative staff that would benefit the target companies and society as a whole with relevant educational background.

Extend training bases. Choose government sectors and corporations as training bases in order to develop leaders with specific skills.

Learn from foreign experts. Invite foreign leadership instructors to deliver seminars for students and organize learning groups for overseas leadership.

\section{3) Intern at Off-Campus Bases}

Recommend outstanding students of leadership training programs to intern at off-campus bases. With the help of supervisors, students enrich their working experiences and increase their personal skills. Some employers have provided job offers.

\section{B. Teamwork}

Students of leadership training programs constantly improve themselves and at the same time, help their peers learn and grasp leadership skills by the ways of seminars, reading sessions, debates and research.

\section{School Courses}

Set up teaching groups of university students' leadership training and offer optional classes. Course modules include public speaking and communication, managerial psychology, creativity and innovate. Besides, micro-lectures "improving public speaking abilities in 30 days", "learn about leadership in 10 minutes" are set with multi-media teaching tools. These courses are released on various internet platforms so that more youth could benefit from them.

\section{EFFECTIVE MEASURES FOR LEADERSHIP EDUCATION OF UNIVERSITY STUDENTS}

\section{A. Teaching Contents: Integrating Educational Resources}

Leadership education of university students should pay attention to integration. Integrating resources means that incampus and off-campus resources should be integrated and make full use of in making plans, process and feedback. Incampus resources include students' extracurricular activities, main courses and research. Off-campus resources include government, corporations and social groups.

\section{B. Teaching Form: Teamwork and Peer Influence}

Leadership education of university students should stress teamwork. Teamwork means that students who have received leadership education should exert influence on peers and youths surrounding them. Student stars and representatives of excellent students from programs of leadership education would attract more fans to join in the study groups due to peer influence.

\section{Teaching Model: Leadership Courses}

Leadership education of university students should be included in the school curriculum, which means more formal and systematic learning. Courses related to leadership education must be in line with school's teaching orientation and goals. Teaching form should gradually shift from lectures to seminars, from face-to-face classroom-based teaching to online lessons. Teaching staff should expand from predominantly current school teachers to recruit the participation of socially famous people and foreign teachers.

\section{REFERENCES}

[1] The nature of executive leadership: A conceptual andempirical analysis of success. Zaccaro,S. J. . 2001

[2] Core competence and education[J] . Gary Holmes,Nick Theory and research on leadership in Organizations. Yulk G,Van Fleet D D. Handbook of Industrial and Organizational Psychology . 1992

[3] Exploring Leadership for College Students Who What to Make a Difference. Susan, Komives,Nance Lucas,Timothy R. McMahon. . 2006 